\title{
PERBANDINGAN PREVALENSI INFEKSI MALARIA TERHADAP PEKERJA DALAM DAN LUAR RUANGAN
}

\author{
Santika, Ilham Tri ${ }^{1}$; Onggowaluyo, Jangkung Samidjo ${ }^{1}$; Kurniawan, Entuy ${ }^{1}$; \\ Suleman, \\ ${ }^{1}$ Jurusan Teknologi Laboratorium Medik Poltekkes Kemenkes Bandung \\ Email : Ilhamsantika1997@gmail.com \\ ABSTRAK
}

\begin{abstract}
Penyakit malaria disebabkan oleh infeksi protozoa dan genus dari Plasmodium yang hidup dan berkembang biak dalam jaringan hati dan sel darah merah manusia yang terinfeksi. Banyaknya kasus endemik dan keadaan luar biasa (KLB) penyakit mlaria yang berkecambuk di suatu daerah menyebabkan korban yang tidak sedikit. Berdasarkan permasalahan tersebut,diatas peneliti tertarik untuk melakukan pengkajian melalui penelitian melihat prevalensi perbandingan infeksi malaria terhadap lingkungan pekerjaan luar ruangan dan pekerja dalam ruangan.dari data jenis pekerjaan yang paling banyak terinfeksi penyakit malaria terbanyak yaitu Buruh tani yang persentasenya 28 orang ,urutan kedua yaitu nelayan yang mendapat presentase 21 orang, urutan ke tiga yaitu pegawai negri sipil (PNS) yang mendapat presentase 13 orang, pada urutan yang keempat yaitu pada ibu rumah tangga 9 orang, selanjutnya di urutan kelima yaitu pekerja tambang senilai 8 orang, dan yang terakhir yaitu pegawai swasta 5 orang (6\%), dengan total 84 orang. Untuk klasifikasi pekerjaan dalam dan luar ruangan di dapatkan dari data pekerjaan yaitu yang paling banyak terinfeksi malaria yaitu pada pekerja luar ruangan 55 orang, dibandingkan pada pekerja dalam ruangan 29 orang. Untuk prevalensi untuk pekerja dalam dan luar ruangan. Didapatkan hasil $65.47 \%$ untuk pekerja dalam ruangan $34 \%$. Adanya perbedaan yang signifikan antara pekerja dalam dan luar ruangan di Kecamatan Simpenan Kabupaten Sukabumi. Untuk penelitain selanjutnya dilakukan penelitian lanjutan untuk mengetahui hubungan antar pekerja luar ruangan terhadap infeksi malaria di Kabupaten Sukabumi.
\end{abstract}

Kata Kunci : Prevalensi 1, Malaria 2, Plasmodium 3, Pekerjaan 4, KLB 5,

\section{ABSTRACT}

Malaria is caused by an infection of the protozoa and genus of Plasmodium which lives and multiplies in the tissues of the liver and red blood cells of infected humans. The number of endemic cases and extraordinary conditions (KLB) of MLARIA disease that flares in an area causes not a few victims. Based on these problems, the researchers were interested in conducting a study through research looking at the prevalence of comparable malaria infections to outdoor work environments and indoor workers. From the data the most types of malaria-infected occupants were farm workers whose percentage was 28 people, the second place is fishermen who get a percentage of 21 people, third place is civil servants (PNS) who get a percentage of 13 people, in the fourth order that is 9 housewives then in fifth place, namely mine workers worth 8 people (9.5\%), and the last is private employees 5 people, with a total of 84 people. For the classification of indoor and outdoor jobs in the data obtained from work that is the most infected with malaria, namely in outdoor workers 55 people, compared to indoor workers 29 people. For prevalence for indoor and outdoor workers. The results obtained $65.47 \%$ for 34\% indoor workers. There is a significant difference between indoor and outdoor workers in Simpenan District, Sukabumi Regency. For further research, further research was conducted to determine the relationship between outdoor workers and malaria infections in Sukabumi District. 


\section{PENDAHULUAN}

Penyakit malaria ini disebabkan oleh infeksi protozoa dan genus dari Plasmodium yang hidup dan berkembang biak dalam jaringan dan hati sel darah merah manusia yang terinfeksi. Penyakit ini secara alami ditularkan (ditransmisikan) dengan perantara vektor nyamuk Anopheles betina. Penyebaran penyakit ini diseluruh dunia sangat tinggi, dan berbanding lurus dengan tingkat penyebaran nyamuk Anopheles ${ }^{1}$.

Peneliti abad 20 menemukan benda berbentuk pisang yang tampak pada sel darah merah yang diwarnai larutan Giemsa yaitu parasit malaria (Plasmodium $s p$ ) dalam stadium gametosit. Stadium sebenarnya ada dua jenit yaitu makrogametosit dan mikro gametosit. Apabila gametosit ini di dalam darah terisap oleh nyamuk, selanjutnya akan tumbuh berubah menjadi makro gametosit dan mikrogametosit.Apabilamakrogamet osit terjadi fertilisasi di dalam kelenjar ludah nyamuk akan berkembang menjadi zigot, ookinet, dan ookista. Apabila ookista akan mengeluarkan ribuan sporozoit, dan masuk ke tubuh manusia melalui gigitan nyamuk Selanjutnya sporozoit berkembang biak secara skizoni dalam jariangan hati dan sel darah merah membentuk parasit malaria stadium tropozoit dan skizon 234 .

Menurut laporan dari WHO tahun 2005 menyebutkan, di seluruh dunia jumlah kasus baru malaria berkisar 300-500 juta orang dengan kematian 2,7 juta orang. Pasien sebagian besar anak-anak di bawah 5 tahun yang merupakan kelompok paling rentan terhadap penyakit dan kematian akibat malaria. $^{2}$

Di Indonesia daerah endemik paling banyak berada di luar pulau Jawa, sementara di Pulau Jawa daerah endemik malaria diantaranya adalah Kabupaten Sukabumi dengan nilai Annual Parasite Index 0,7 pada tahun 2011. Pada bulan Mei 2012 telah tercatat kasus malaria sebanyak 135 , terdiri dari 113 merupakan kasus penyakit malaria impor dan 22 lokal. Sebaran penyakit ini banyak ditemukan di 8 wilayah kecamatan,salah satunya Kecamatan Simpenan. ${ }^{19}$.

Penyakit malaria salah satunya di sebabkan dari lingkungan pekerjaan yang tidak sehat, yaitu terdapat banyaknya genangan air di lingkungan pekerjaan ataupun lingkungan yang tidak bersih. Tidak hanya itu, nyamuk Anopeles dapat berkembang biak di dalam ruangan dengan suhu yang hangat, Sehingga dapat mempercepat siklus hidup nyamuk Anopeles. Maka dari itu, resiko untuk terkena penyakit infeksi malaria tidak hanya menyerang para pekerja di luar ruangan saja, akan tetapi pekerja dalam ruanganpun dapat terkena resiko infeksi malaria ${ }^{4}$ 12.

Banyak kasus endemik dan kedaan luar biasa (KLB) penyakit malaria yang berkecambuk di suatu daerah menyebabkan korban yang tidak sedikit. Hal ini kurangnya perhatian dari pemerintah terkait (Kementrian Kesehatan RI) terutama dalam mengantisipasi dan mengevaluasi munculnya penyakit malaria, walaupun kasusnya belum terjadi sporadik di suatu daerah. ${ }^{5}$

$$
\text { Kecamatan }
$$

Simpenan Kabupaten Sukabumi merupakan salah satu dari 16 Kecamatan yang dinyatakan endemis malaria di Kabupeten Sukabumi. Dari data diberikan Dinas Kesehatan Divisi P2PM Kecamatan Simpenan terakhir mengalami Kasus endemis malaria pada tahun 2015. ${ }^{711}$

Berdasarkan permasalahan tersebut, di atas Peneliti tertarik untuk melakukan pengkajian melalui penelitian untuk melihat prevalensi perbandingan infeksi malaria terhadap Lingkungan 
Pekerja luar ruangan dan pekerjaan dalam ruangan. Hal ini mengingat angka prevalensi penyakit malaria di beberapa desa Kecamatan Simpenan Kabupaten Sukabumi masih cukup besar di warga Kabupaten Sukabumi.

\section{METODE Desain dan Objek}

Desain penelitian ini adalah Perbandingan dua kelompok yang bekerja di luar ruangan dan pekerja dalam ruangan yang terinfeksi penyakit malaria di Kecamatan Simpenan Kabupaten Sukabumi. Penelitian ini dilakukan dengan menggunakan preparat malaria hasil validasi Puskesmas dan Dinas Kesehatan Kabupaten Sukabumi.

\section{Jenis Data,Populasi,Sempel dan Analisis data}

Data yang digunakan dalam penelitian ini adalah data primer dan data sekunder. Data primer di peroleh dari preparat yang langsung didapatkan dari Dinas Kesehatan Kabupaten Sukabumi. Dalam hal ini pekerja luar ruangan dan pekerja dalam ruangan yang terinfeksi malaria, yang langsung di lihat di bawah mikroskop. Data sekunder didapat dari Dinas Kesehatan Kabupaten Sukabumi berupa catatan rekam medis orang yang terinfeksi malaria di Kabupaten Sukabumi. Populasi penelitian adalah orang-orang yang berdomisili dibeberapa di Kecamatan Simpenan Kabupaten Sukabumi (Pekerja di luar ruangan dan pekerja dalam ruangan).Sempel ditetapkan dengan menggunakan rumus Solvin (Umar,2014)

Jumlah populasi dalam penelitian ini adalah sebanyak 482 orang yang terinfeksi malaria dalam 5 tahun terakhir. Sehingga presentase kelonggaran yang digunakan adalah $10 \%$ dan hasil perhitungan dapat di bulatkan untuk mencapai kesesuaian. Maka untuk mengetahui sempel penelitian, dengan Perhitungan sebagai berikut:

Berdasarkan perhitungan di atas, sempel yang menjadi responden dalam penelitian ini di sesuaikan menjadi sebanyak 83 orang atau sekitar $17 \%$ dari seluruh total yang terinfeksi malaria. Data penelitian akan diolah dengan statistical program for social scince (SPSS), Metode distribusi frekuensi.

\section{Hasil Penelitian}

\section{Gambaran umum lokasi penelitian}

Kecamatan Simpenan adalah salah satu daerah dari 16 Kecamatan yang endemis malaria. Kecamatan Simpenan mempunyai luas $17.360 \mathrm{Ha}$ dengan penduduk berjumlah 48.281 jiwa yang terbagi dalam 6 desa yang terdiri dari Desa Cihaur, Kertajaya, Loji, Cidadap, Cibuntu, dan Mekarasih.

\section{Karakteristik Responden}

Responden dalam penelitian ini adalah sebanyak 84 orang dimana responden berasal dari kalangan pekerja dalam dan luar ruangan yang terinfeksi malaria

\section{a. Umur}

Responden yang diambil oleh peneliti adalah umur produkif antara 15-65 tahun. Hal ini karnakan jumlah infeksi malaria yang paling banyak menginfeksi masyarakat di Kecamatan Simpenan Kabupaten Sukabumi ialah umur produktif.

b. Jenis Kelamin

Dari data distribusi frekuensi yang di ambil dalam penelitian ini sekitar 76,2\% laki-laki (64 orang) dan $23 \%$ perempuan (23 orang) dengan total 100\% (84 orang) responden.

c. Jenis pekerjaan 
JURNAL RISET KESEHATAN

POLTEKKES DEPKES BANDUNG

Volume 11 No 1

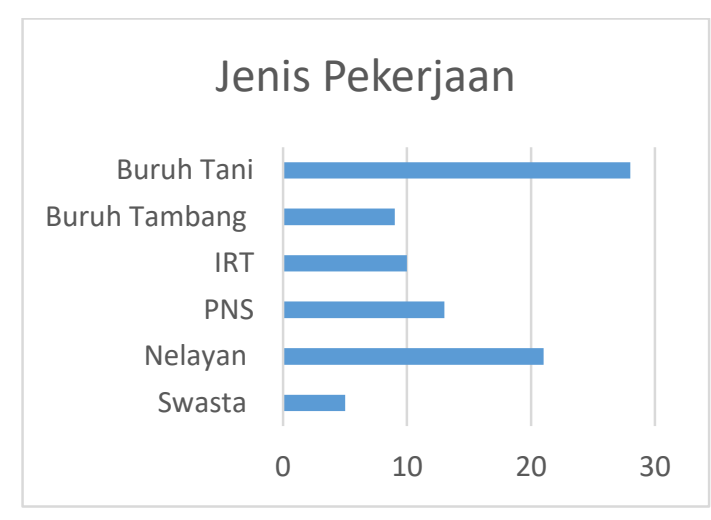

Gambar 1 Distribusi Frekuensi Jenis pekerjaan

Dari data jenis pekerjaan yang paling banyak terinfeksi penyakit malaria terbanyak yaitu pada Buruh tani yang mendapat presentase 28 orang $(33,3 \%)$, urutan kedua yaitu Nelayang yang mendapat 21 orang (25\%), urutan ketiga yaitu Pegawai Negri Sipil (PNS) yang mendapat presentase 13 orang $(15,5 \%)$, pada urutan keempat yaitu pada Ibu Rumah Tangga 9 orang (10,7 $\%)$, selanjutnya di urutan kelima yaitu pada Pekerja Tambang senila 8 orang $(9,5 \%)$, dan yang terakhir yaitu pegawai Swasta 5 orang $(6 \%)$. Dengan total $100 \%$ (84 orang).

d. Klasifikasi pekerjaan

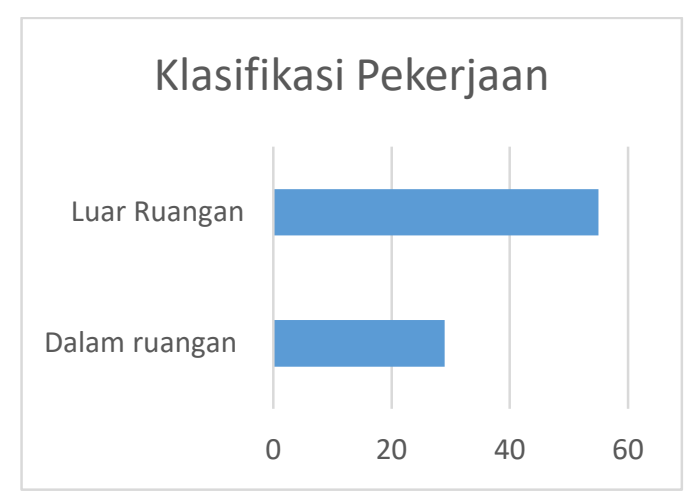

Gambar 2 Distribusi Frekuensi Klasifikasi Pekerjaan

Data yang di dapatkan dari data pekerjaan yaitu yang paling banyak terinfeksi malaria yaitu pada Pekerja luar ruangan yang dapat presentase 55 orang $(65 \%)$ di banding pada Pekerja dalam ruangan 29 orang $(34,5 \%)$.

\section{Distribusi frekuensi Malaria}

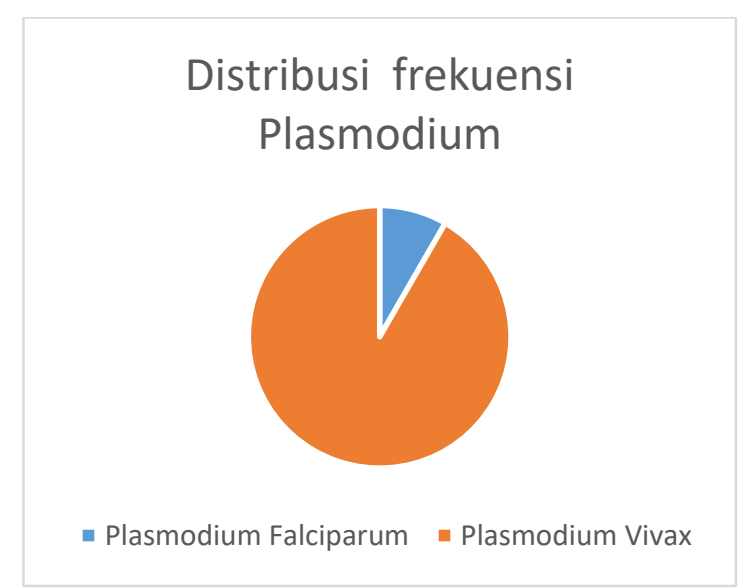

Gambar 3 Distribusi Ferkuensi Plasmodium

Pada data diatas didapatkan hasil distribusi frekuensi parasit jenis parasit yang paling banyak di temukan prearat yaitu Plasmodium Vivax senilai 77 orang $(91,7 \%)$ untuk Plasmodium Falciparum ditemukan 7 orang $(8,3 \%)$

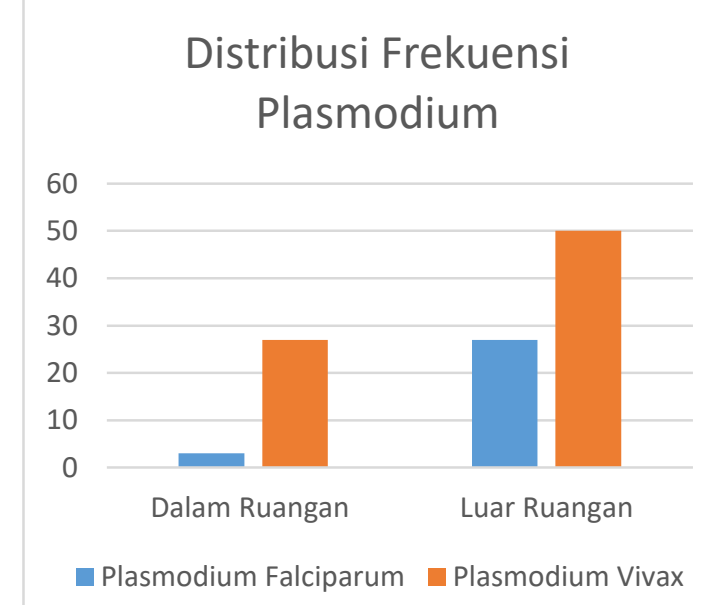

Gambar 4 Distribusi Frekuensi Plasmodium

Berdasrkan data distribusi frekuensi Plasmodium berdasarkan klasifikasi pekerjaan di temukan dari 77 $(91 \%)$ orang yang terinfeksi malaria spesies Plasmodium Vivax, 27 orang yang bekerja di dalam ruangan dan 50 orang bekerja di luar ruangan, sedangkan dari 7 orang $(8,3 \%)$ orang yang terinfeksi malaria spesies Plasmodium Falciparum, 3 orang yang bekerja dalam ruangan dan 4 orang yang bekerja dalam luar ruangan.

\section{Prevalensi infeksi malaria}

Berdasarkan gambaran Prevalensinya, penduduk yang bekerja di luar ruangan 
JURNAL RISET KESEHATAN

POLTEKKES DEPKES BANDUNG

Volume 11 No 1

lebih banyak terserang malaria dibanding pekerja dalam ruangan

Pekerjaan luar ruangan

$$
\begin{aligned}
\text { Prevalensi }= & \frac{41+14}{84} \times 100 \\
& =65.47 \%
\end{aligned}
$$

Pekerja dalam ruangan

$$
\begin{aligned}
\text { Prevalensi }= & \frac{23+6}{84} \times 100 \\
& =34.5 \%
\end{aligned}
$$

Dari hitungan prevalensi antara pekerja yang ada dalam dan luar ruangan mengalami perbedaan $30,97 \%$ lebih besar pekeja dalam ruangan.

Di Puskesmas Simpenan Kabupaten Sukabumi, dalam priode tiap tahun di temukan penderita malaria. Berdasarkan riwayatnya, bahkan Puskesmas simpenan pernah dinyatakan secara darurat sebagai wilayah daerah hiperendemik atau daerah dalam status Kejadian Luar Biasa (KLB). Dalam kondisi ini, penderita malaria prevalensinya cukup tinggi, parasit penyebab banyaknya ditemukan stadium gametosit (makrogametosit dan mikrogametosit), spesies vektor yang ditemukan dalam jenis dan jumlah yang tinggi karena banyak berbagai tempat perindukan (breeding place) yang mendukung eksistensi kehidupan dan daur hidup nyamuk penyebabnya (vektor). Penduduk yang bertempat tinggal atupun bekerja di tempat-tempat potensial untuk mendukung mekanisme terjadinya penularan infeksi malaria. Misalnya di sekitar pemukiman atau pekerjaan banyak di temukan vegetasi (jenis tumbuhan), kandang-kandang ternak, kolam-kolam ikan. Keberadaan Vegetasi di sekitar area pemukiman penduduk, dapat digunakan untuk tempat istirahat tetap (permanent resting) vektor malaria dapat mempercepat produksi telur. Kandangkandang ternak (tempat bekerja) merupakan tempat vektor untuk

mendapatkan makanan berupa hewan ternak dan manusia, karna berdasarkan survei lapangan oleh Dinas Kesehatan setempat yang dinamakan Penanganan Pencegahan penyakit Menular (P2PM), banyak ditemukan jenis vektor yang bersifat antrofobilik (lebih senang menggigit manusia), zoofilik (lebih senang menggigit hewan), zooantrofobilik (mengambil darah hewan dan manusia).

\section{Pembahasan}

Bedasarkan data dari 84 pasien yang terinfeksi penyakit malaria 28 orang (33\%) bekerja sebagai buruh tani. Hal ini karena sering berada di tempattempat perindukan vektor nyamuk yang bersifat eksofilik (nyamuk lebih suka beristirahat di luar ruangan). Hal ini sesuai dengan penelitian sebelumnya yaitu dalam melakukan uji kepadatan vektor malaria, dari hasil penangkapan beberapa jenis spesies sekitar vektor Anopheles sinensis sekirat 50\%. Anopheles sinensis adalah vektor utama malaria, yang banyak menginfeksi masyarakan Kecamatan Simpenan Kabupaten Sukabumi. Berdasarkan data yang didapat tabel 4.4 yang paling banyak menginfeksi masyarakat Kecamatan Simpenan Kabupaten Sukabumi, yaitu Plasmodium vivax $97 \%$ Di wilayah Kecamatan Simpenan Kabupaten Sukabumi kasus malaria disebabkan banyak di sebabkan oleh parasit malaria spesies Plasmodium vivax. secara epidemologik malaria yang disebabkan oleh parasit ini menunjukan adanya kesinambungan, baik dalam hal gejala klinik muncul maupun penularannya. Spesies parasit ini dapat menimbulkan kakus relaps (kambuh) pada penderitanya, karena dalam kelangsungan hidup dan siklusnya berlangsung secara intraeritrosit (dalam sel darah merah), dan ektraeritrosit (di dalam jaringan parenkin hati). Spesies parasit ini melangsungkan skizogoni pada eritrosit dan jaringan hati, sehingga apabila terjadi sporulasi (pecahnya Skizon) 
JURNAL RISET KESEHATAN

POLTEKKES DEPKES BANDUNG

Volume 11 No 1

akan menimbukan kerusakan pada eritrosit dan sel-sel hati tersebut.

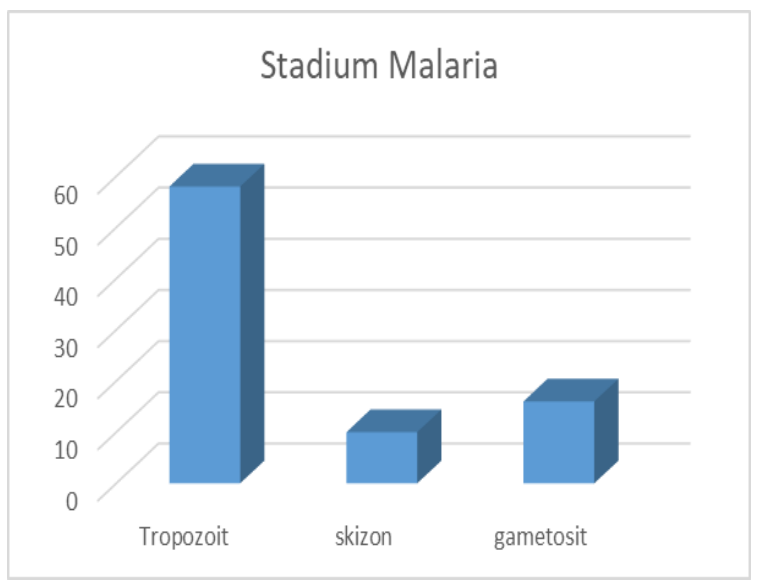

Gambar 5 Distribusi Frekuesnsi Malaria

Berdasarkan kurva hasil pemeriksaan stadium malaria yang ditemukan pada 84 orang pada preparat ditemukan Tropozoit $69 \%$ (55 orang), skizon $11.9 \%$ (10 orang), gametosit $10 \%$ (16 orang).

Stadium tropozoit pada pemeriksaan mikroskopis ditemukan yang paling dominan yaitu 69\% (55 orang), dan jumlah ini sangat melonjak tinggi dibanding jumlah stadium lain. Berdasarkan hasil pemeriksaan mikroskopis, stadium ini memiliki bentuk yang beragam, mulai dari bentuk cincin awal, cincin dewasa, dan cincin ameboid. ${ }^{8}$

Stadium skizon pada hasil pemeriksaan mikroskopis ditemukan dalam jumlah 10 orang (11,9\%), stadium ini yang paling sedikit di temukan pada preparat. Apabila ditemukan stadium skizon muda, skizon dewasa, dan skizon tua bisa dihubungkan dengan gejala klinik lanjut malaria. ${ }^{9}$

Stadium gametosit pada hasil pemeriksaan mikroskopis dari 84 sempel terdapat $19 \%$ (16 orang ). Satadium ini lebih banyak di temukan dalam preparat di bandingkan skizon. Stadium gametosit ditemukan dalam dua tipe, yaitu makrogametosit dan mikrogametosit. Berdasarkan bentuk pertumbuhannya, stadium gametosit dalam perkembangannya sama seperti stadium lainnya. Gametosit dapat dibedakan menjadi gametosit muda, gametosit dewasa, gametosit tua. Dari ketiga stadium tersebut yang berisfat infektif adalah gametosit tua. Makrogametosit tua dan mikrogametosit tua yang berada dalam darah hospes pelantrara. ${ }^{11}$

\section{Simpulan}

Prevalensi penyakit malaria yang bekerja di luar ruangan di Kecamatan Simpenan Kabupaten Sukabumi senilai $65.4 \%$. Prevalensi penyakit malaria yang di dalam ruangan di Kecamatan Simpenan Kabupaten Sukabumi senilai $34.5 \%$ Adanya perbedaan 30,39\% antara pekerja dalam dan luar ruangan di Kecamatan Simpenan Kabupaten Sukabumi. Dan saran untuk penelitian selanjutnya perlu adanya penelitian lebih lanjut mengenai faktor-faktor yang menintervensi keadaan prevalensi malaria di wilayah Kabupaten Sukabumi, perlu adanya penelitian mengenai jenis vektor yang Menjelaskan Malaria yang ada di wilayah Kecamatan Simpenan Kabupaten Sukabumi.

\section{Daftar Rujukan}

1. Sadeli, Martius. Profilaksis Malaria.

Padang : Fakultas kedokteran Universitas andalas, 2000.

2. Anonymus. Word Malaria Report 2005. Geneva : RBN/WHO/UNICEF, 2005.

3. Anonim. Sistem Survelis Dalam Program Penanggulangan Malaria Di Indonesia. Jakarta : Depkes RI, 2002.

4. Harjianto, P.N. Epidemiologi, Patogenesis, Manifestasi klinis, dan penanganan . Jakarta : EGC, 2000.

5. Gandhahusada, et al. Parasitologi Kedoteran. Jakarta : Fakultas Kedokteran Universitas Indonesia , 1998. 
JURNAL RISET KESEHATAN

POLTEKKES DEPKES BANDUNG

Volume 11 No 1

6. Pramita, Anggun. Koreksi Referensi Nyamuk Di Daerah Endemis .

Banjarnegara : s.n., 2014.

7. Tooy, DJ, Bernandus, JB dan Sirosi, A. Deteksi Plasmodium dengan menggunakan real-time polymerase chain reaction.

Manado : Universitas Sam Ratulangi Manado, 2013.

8. Wibawa, Panji. Studi Bioekologi Nyamuk Anopheles Sundaicus. Vol.41 . ciamis : s.n., 2013.

9. Zurkarmain, I. Buku Ajar Ilmu Penyakit Dalam . 6nd. Jakarta : Balai Penerbit FKUI, 2006.

10. Lasagna, I. Kapita Selekta Kedoketeran Klini . Jakarta : Bina Rupa Aksara, 2009.
11. WHO. Word Malaria Report 2005. Geneva : RBN/WHO/UNICEF, 2005.

12. Knols, B.G.J dan Takken. Malaria Vector Control: Current and future stratgiess. Laboratory Of Entomology. Netherland : wegeningen University And Research Center, 2008.

\section{Departemen Kesehatan} RI.Epidemiologu Penyakit malaria. Pemberantasa Penyakit Menular dan PenehatanLingkungan Pemukiman . Jakarta : Departemen Kesehatan RI, 2010. 